\title{
Epidemiology of Soybean vein necrosis-associated virus
}

\author{
Jing Zhou and Ioannis E. Tzanetakis
}

Department of Plant Pathology, Division of Agriculture, University of Arkansas System, Fayetteville 72701. Accepted for publication 27 March 2013.

\begin{abstract}
Zhou, J., and Tzanetakis, I. E. 2013. Epidemiology of Soybean vein necrosis-associated virus. Phytopathology 103:966-971.

Soybean vein necrosis-associated virus has been linked to an emerging soybean disease in the United States and Canada. Virus distribution and population structure in major growing areas were evaluated. Data were employed to design and develop sensitive detection protocols, able to

detect all virus isolates available in databases. The host range for the virus was assessed and several species were found to sustain virus replication, including ivyleaf morning glory, a common weed species in soybeangrowing areas in the United States. Koch's postulates were fulfilled using soybean thrips and transmission efficiency was determined. This article provides significant insight into the biology of the most widespread soybean virus in the United States.
\end{abstract}

Soybean vein necrosis disease (SVND) was first reported in Arkansas and Tennessee in 2008 (40). SVND symptoms include leaf chlorosis and necrosis varying from minor vein clearing to leaf necrosis (Fig. 1). Testing for 16 viruses or virus groups failed to identify the causal agent (40). A tentative new virus with typical Tospovirus genome organization consisting of a 16.5-kb tripartite, ambisense, single-stranded RNA named Soybean vein necrosis-associated virus $(\mathrm{SVNaV})$ was detected in symptomatic material (46). Putative SVNaV proteins shared minimal similarity with tospoviruses and phylogenetic analysis revealed the virus's unique placement in the evolutionary history of the genus $(6,46)$

Tospoviruses are some of the most devastating pathogens affecting global agriculture $(10,27)$. Several members in the genus, including Tomato spotted wilt virus, Groundnut ringspot virus, and Tomato yellow fruit ring virus, naturally infect soybean (11, 12,28). Tospoviruses are the only phytopathogens in the family Bunyaviridae and are transmitted by 14 thrips species (order Thysanoptera). Virus acquisition is a life-stage-dependent process, given that thrips are only able to acquire tospoviruses in the first two larval stages and then transmit in a persistent, propagative manner $(25,30,31,41-43)$.

Since its discovery, SVNaV and SVND have expanded from the south-central United States to all major soybean-producing areas of North America, and SVNaV is now considered the most widespread soybean virus in the United States, found in more than $98 \%$ of visited fields (46). The importance of tospoviruses and the widespread presence of SVNaV led to further study of the virus epidemiology, including distribution, population structure, detection, host range, vectors, and fulfillment of Koch's postulates. The information obtained in this study provides insight into an emerging disease in one of the most important agricultural crops.

Corresponding author: I. E. Tzanetakis; E-mail address: itzaneta@uark.edu

*The $\boldsymbol{e}$-Xtra logo stands for "electronic extra" and indicates that Figures 1, 3, 4, and 5 appear in color online.

http://dx.doi.org/10.1094/PHYTO-12-12-0322-R

(c) 2013 The American Phytopathological Society

\section{MATERIALS AND METHODS}

SVNaV distribution and incidence. More than 700 samples, symptomatic and asymptomatic, were collected between 2008 and 2012 from Arkansas (AR, 228 samples), Delaware (DE, 4 samples), Illinois (IL, 30 samples), Kansas (KS, 12 samples), Kentucky (KY, 3 samples), Maryland (MD, 4 samples), Mississippi (MS, 16 samples), Missouri (MO, 387 samples), New York (NY, 10 samples), Pennsylvania (PA, 6 samples), and Tennessee (TN, 3 samples), and were tested for $\mathrm{SVNaV}$ using the detection protocol of Zhou et al. (46) or the one described in this article.

Population structure. SVNaV isolates were collected from samples exhibiting different degrees of disease severity (Fig. 1) from AR, DE, IL, KS, MD, MS, MO, and TN between 2008 and 2012. Total nucleic acids were isolated as previously described (39) and reverse-transcription polymerase chain reaction (RTPCR) was performed using the oligonucleotide primers SdetF/ SdetR that amplify the complete nucleoprotein gene (NP) (46). Amplicons were cloned in vector pCR2.1 (Life Technologies, Grand Island, NY) as previously described (46) and sequenced using the M13F/R primers at the DNA Resource Center of the University of Arkansas. Sequences were visualized using Sequence Scanner Software v1.0 (Applied Biosystems, CA). Contigs of the complete NP gene of 37 isolates, with a minimum $3 \times$ nucleotide coverage, were obtained using CAP3 (14). Corrected sequences together with all other NP sequences available in GenBank (accessed December 2012) were aligned using ClustalW 2 (20). Diversity, segregating sites, and genetic distance were analyzed using MEGA v.5 (37). Neutrality tests were performed using Tajima's D method (36) and the ratio of nonsynonymous substitutions per nonsynonymous site $\left(\mathrm{d}_{\mathrm{Ns}}\right)$ over synonymous substitutions per synonymous site $\left(\mathrm{d}_{\mathrm{S}}\right)$ was calculated using SNAP (18).

Detection. NP gene alignments were used as the matrix for the development of several sets of detection oligonucleotide primers (data not shown). One of the sets, SVNaV-NPF (5'-ACTTG TGCAAGCTTATGGT-3') and SVNaV-NPR (5'-GAAATGATTC CAATCTGTTC-3'), that amplifies a 348-nucleotide fragment of the NP gene, provided the best amplicons in the pilot studies and could amplify all isolates found in the databases. The sensitivity of the assay was evaluated using different numbers of PCR cycles (20 or 30) and was repeated three times. Briefly, nucleic acids were treated with RNase-free DNaseI according to the manu- 
facturer's instruction (Thermo Fisher, Waltham, MA) and RNA with concentrations of 1,10 , and $100 \mathrm{ng}$ were used in cDNA synthesis, as previously described (46). Three biological replicates were employed for each RNA concentration. The $25-\mu 1$ PCR reactions consisted of $0.2 \mathrm{mM}$ dNTPs, $0.4 \mu \mathrm{M}$ SVNaV-NPF/ SVNaV-NPR, $0.1 \mathrm{U}$ of Taq polymerase, and $2.5 \mu \mathrm{l}$ of cDNA template. The program initiated with predenaturation at $94^{\circ} \mathrm{C}$ for $2 \mathrm{~min}$; followed by different numbers of cycles with denaturation at $94^{\circ} \mathrm{C}$ for $30 \mathrm{~s}$, annealing at $50^{\circ} \mathrm{C}$ for $10 \mathrm{~s}$, and extension at $72^{\circ} \mathrm{C}$ for $30 \mathrm{~s}$; followed by a final extension at $72^{\circ} \mathrm{C}$ for $10 \mathrm{~min}$.

Host range. In total, 25 species belonging to 10 plant families were used in the study (Table 1). Lesions from SVNaV-positive soybean leaves were ground in a precooled mortar and pestle with chilled, fresh phosphate buffer $(0.1 \mathrm{M}, \mathrm{pH} 7.2)$ containing $0.1 \%$ ( $\mathrm{vol} / \mathrm{vol})$ 2-mercaptoethanol at a 1:10 (wt/vol) ratio. Sap was inoculated onto plants kept in the dark overnight and dusted with carborundum (600 mesh). Plants were monitored in the greenhouse for symptoms and tested for the presence of SVNaV approximately a month postinoculation using RT-PCR. For each species, at least 10 plants were inoculated and tested for virus infection. In addition, Ipomoea hederacea Jacq. (Ivyleaf morning glory) plants were collected from a field with high SVND incidence and tested for the virus.

Koch's postulates. SVNaV purification using the protocol published by Mohamed and colleagues (24) proved unsuccessful.
Purification of virus isolates using local lesion hosts also proved futile because SVNaV lost infectivity after the second passage (45). For this reason, thrips were used as the means of virus transmission and reconstruction of disease symptoms. Populations of Sericothrips variabilis (family Thripidae, subfamily Sericothripinae; soybean thrips) were collected from soybean fields and reared in the laboratory. Colonies were established on $\mathrm{SVNaV}$-free soybean plants and maintained at $28 \pm 0.5^{\circ} \mathrm{C}$ with a 12 -h photoperiod in a growth chamber. Larvae were collected within $24 \mathrm{~h}$ of hatching and used in transmission studies as described by Inoue (15), with minor modifications. Briefly, 20 to 30 larvae, numbers commonly found on soybean plants in the mid-south, were transferred to $\mathrm{SVNaV}$-infected soybean leaves placed in petri dishes. After a 24- to 48-h acquisition period at $28 \pm 0.5^{\circ} \mathrm{C}$, all larvae were transferred to SVNaV-free soybean seedlings ('Hutcheson') and maintained within cages under greenhouse conditions for symptom development. Larvae fed on $\mathrm{SVNaV-free} \mathrm{soybeans} \mathrm{were} \mathrm{transferred} \mathrm{to} \mathrm{'Hutcheson'} \mathrm{as} \mathrm{a} \mathrm{nega-}$ tive control. All plants were kept in thrips-proof cages to prevent contamination with other thrips species. The presence of SVNaV was determined using the detection protocol of Zhou et al. (46), with amplicons sequenced to confirm virus infection.

Transmission efficiency. Soybean thrips larvae were reared as described above and 30 individuals were placed on individual 'Hutcheson' plants. Three replicates consisting of seven, eight, or
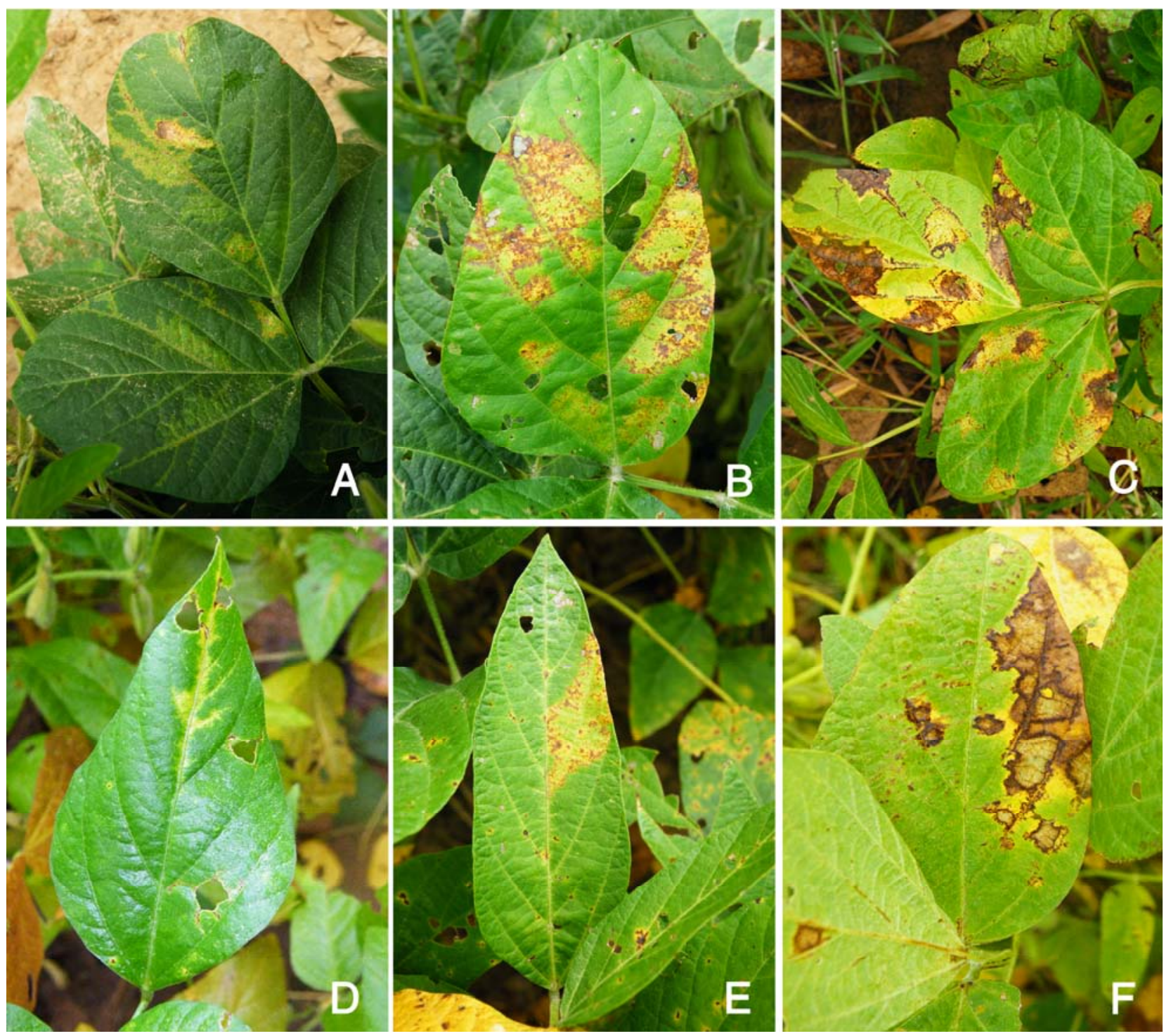

Fig. 1. A and D, Early; $\mathbf{B}$ and E, mid-season; and $\mathbf{C}$ and F, late-season field symptoms on soybean infected with Soybean vein necrosis-associated virus. 
nine plants were used in transmission efficiency studies. In addition, nine 'Lee 68' plants were used in an experiment designed to validate the results obtained with 'Hutcheson'.

\section{RESULTS}

SVNaV distribution and incidence. $\mathrm{SVNaV}$ was detected in all 576 symptomatic samples collected from AR $(n=175)$, DE $(n=3), \mathrm{IL}(n=12), \mathrm{KS}(n=8), \mathrm{KY}(n=1), \mathrm{MD}(n=3), \mathrm{MS}(n=$ $10)$, MO $(n=348) \mathrm{NY}(n=8)$, PA $(n=6)$, and TN $(n=1)$ but in none of the 127 symptomless samples collected from heavily SVNaV-infested fields. These data confirmed the close association between vein necrosis disease symptoms and the presence of $\mathrm{SVNaV}$. The occurrence of $\mathrm{SVNaV}$ has also been verified in several additional states $(3,10,13,16,21,33,38)$. Disease incidence was highly variable among fields, 10 to $80 \%$ depending on growth stage and geographic areas. Symptom intensities also exhibited cultivar-dependent patterns, with mild infections causing thread-like vein clearing whereas severe infections resulted in dark necrotic lesions expanding to the majority of the leaf blade.

Population structure. The NP gene has commonly been used in tospovirus diversity studies $(7,19,26)$ and was also chosen to evaluate the SVNaV population structure. The nucleotide sequences of 37 isolates collected from AR, DE, IL, KS, MD, MS, and TN were determined and deposited in GenBank as accession numbers HQ728355-84, HQ728386, and JQ946869-74. Together with 11 isolates from $\mathrm{KY}$ and $\mathrm{TN}$ (17) (accession numbers JF808207-13, JF8082115, and JQ277450-52), 48 isolates were used to analyze the population structure of the virus. Pairwise comparisons revealed identities of 98 to $100 \%$ at the nucleotide level and 97 to $100 \%$ at the amino acid level (data not shown), suggesting that $\mathrm{SVNaV}$ has a relatively homogeneous population structure within the geographic areas studied.

The mean overall genetic distance between all isolates was 0.007 , with little intrastate and interstate variation of 0.005 to 0.012 . Sequences formed a monophyletic cluster lineage and the phylogenetic analysis did not reveal a distinct geographical pattern in isolate clustering (data not shown). These results indicate that no significant diversity exists within or among populations in the states studied, minimizing the possibility of distinct virus strains causing the observed differences in disease severity. The value for Tajima's D neutrality test was negative and genetic segregation was detected in 94 loci among 55 isolates. The $\mathrm{d}_{\mathrm{Ns}} / \mathrm{d}_{\mathrm{S}}$ ratio was 0.16 , indicating minimal genetic variation within virus populations with dominant purification selection.

Detection. The SVNaV-NP forward/reverse (F/R) primer set confirmed the presence of SVNaV in all SVND material tested and never gave amplicons in negative controls. The sensitivity of the test was $\approx 4$ and $400 \mathrm{pg}$ of RNA after 30 or 20 PCR cycles, respectively (Fig. 2). These results suggest that SVNaV-NP F/R has both universality and sensitivity, providing a useful, efficient tool for virus detection.

Host range. Of the 25 mechanically inoculated plant species, 9 sustained virus replication, as confirmed by RT-PCR and amplicon sequencing (Table 1). Plants tested included weeds indigenous to soybean fields and species commonly used as tospovirus indicators such as Chenopodium quinoa, Dahlia variabilis, Gomphrena globosa, Nicotiana benthamiana, N. glutinosa, and $N$. tabacum $(5,34)$. Symptoms were first observed on $N$. benthamiana, N. glutinosa, N. tabacum, Vigna unguiculata, and $V$. radiate 5 to 7 days postinoculation (Figs. 3 and 4), with the

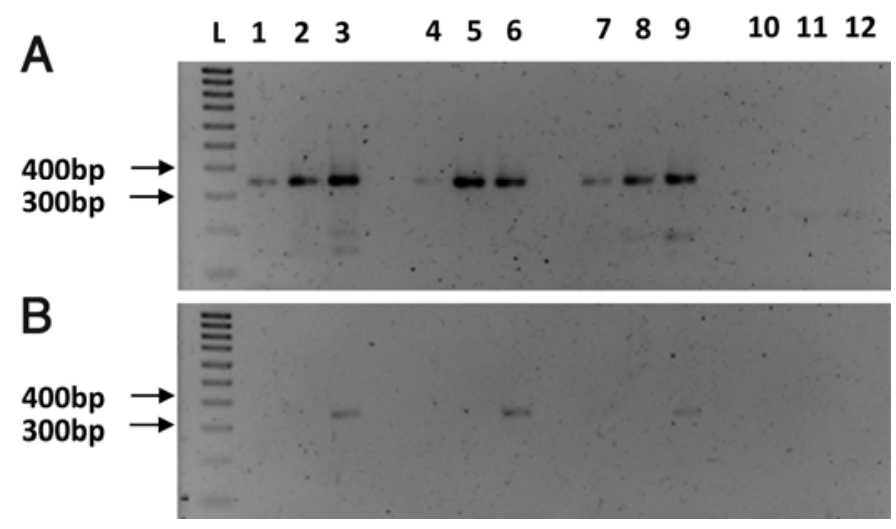

Fig. 2. Reverse-transcription polymerase chain reaction (RT-PCR) detection of Soybean vein necrosis-associated virus $(\mathrm{SVNaV})$ using primers $\mathrm{SVNaV}$ NPF/SVNaV-NPR. A, Detection after 30 PCR cycles; B, detection after 20 PCR cycles. L, DNA ladder; lanes 1 to 9, SVNaV-infected samples; lanes 1 to 3 , replicate 1 ; lanes 4 to 6 , replicate 2 ; lanes 7 to 9 , replicate 3 ; and lanes 10 to 12 , negative controls. RNA concentrations used in each samples: lanes 1,4 , and 7, $4 \mathrm{pg}$; lanes 2, 5, and 8, $40 \mathrm{pg}$; lanes 3,6, and 9, $400 \mathrm{pg}$.

TABLE 1. Plant species used in host range study of Soybean vein necrosis-associated virus and test results

\begin{tabular}{|c|c|c|c|}
\hline Family tested & Species tested & Infected/inoculated & Symptom \\
\hline \multirow[t]{3}{*}{ Amaranthaceae } & Gomphrena globosa & $0 / 10$ & $\ldots$ \\
\hline & Palmer amaranth & $0 / 10$ & $\ldots$ \\
\hline & Spinacia oleracea L. & $0 / 11$ & $\ldots$ \\
\hline & Dahlia hortensis & $0 / 10$ & $\ldots$ \\
\hline Brassicaceae & Brassica oleracea & $0 / 11$ & $\ldots$ \\
\hline \multirow[t]{2}{*}{ Chenopodiaceae } & Chenopodium quinoa & $0 / 10$ & $\ldots$ \\
\hline & C. album & $0 / 10$ & $\ldots$ \\
\hline & Cucurbita pepo L. & $3 / 11$ & Asymptomatic \\
\hline \multirow[t]{5}{*}{ Leguminosae } & Glycine max & $3 / 11$ & Local lesion \\
\hline & Arachis hypogaea & $0 / 12$ & $\ldots$ \\
\hline & Vigna unguiculata & $60 / 80$ & Local lesion \\
\hline & V. radiata & $4 / 10$ & Local lesion \\
\hline & Phaseolus vulgaris & $0 / 11$ & $\ldots$ \\
\hline Malvaceae & Gossypium L. & $0 / 10$ & $\ldots$ \\
\hline & N. tabacum & $8 / 10$ & Local lesion \\
\hline & N. glutinosa & $7 / 10$ & Local lesion \\
\hline & Solanum lycopersicum & $0 / 11$ & $\ldots$ \\
\hline & Capsicum аппиит & $0 / 10$ & $\ldots$ \\
\hline
\end{tabular}


presence of the virus detected at the same time. $N$. benthamiana, the most susceptible host evaluated, was used as an indicator of the effectiveness of each inoculation experiment. Virus replication was confined only on the inoculated leaves of the three legume species used (Fig. 4). Hutcheson soybean was recalcitrant to mechanical inoculation compared with $N$. benthamiana and the infection rate $(27.3 \%)$ was relatively low compared with thrips transmission (100\%). The virus was also detected in symptomless Cucurbita pepo L., Dendranthema grandiflorum, and I. hederacea Jacq. (Ivyleaf morning glory). Ivyleaf morning glory is an indigenous weed species in soybean fields and, for this reason, we surveyed for natural infection in the field. Eight plants were randomly collected from $\mathrm{SVNaV}$-infested soybean fields in AR and tested for the virus by RT-PCR. Five plants were found infected, as confirmed by amplicon sequencing.

Koch's postulates. Five SVNaV-free soybean seedlings were inoculated with soybean thrips larvae fed on material exhibiting SVND symptoms. Visual symptoms expressed as vein clearing along main veins were first observed 2 weeks postinoculation (wpi). Vein clearing turned to chlorosis, subsequently turning necrotic and expanding to the majority of the leaf blade (Fig. 5).
At 4 wpi, all plants inoculated by thrips larvae developed symptoms and all tested positive using RT-PCR followed by sequencing of the products to verify results, all of which were virus specific. None of the control plants inoculated with thrips that fed on SVNaV-free soybeans developed symptoms or tested positive for the virus.

Transmission efficiency. Transmission efficiency was determined after 30 soybean thrips larvae were transferred to 'Hutcheson' and allowed a 24- to 48-h acquisition access period. At 4 wpi, all inoculated plants showed typical vein necrosis disease symptoms and all tested positive for the virus using RT-PCR, with a $100 \%$ transmission efficiency. Experiments with Lee 68, used to confirm transmission, showed $67 \%$ efficiency (Table 2). Several amplicons were sequenced to confirm the identity of the amplicons and they were all found to be virus specific.

\section{DISCUSSION}

$\mathrm{SVNaV}$ is a new virus present in several states in the United States and Ontario, Canada $(3,10,13,16,21,33,38,46)$. A few other viruses, including Alfalfa mosaic virus, Bean pod mottle virus,
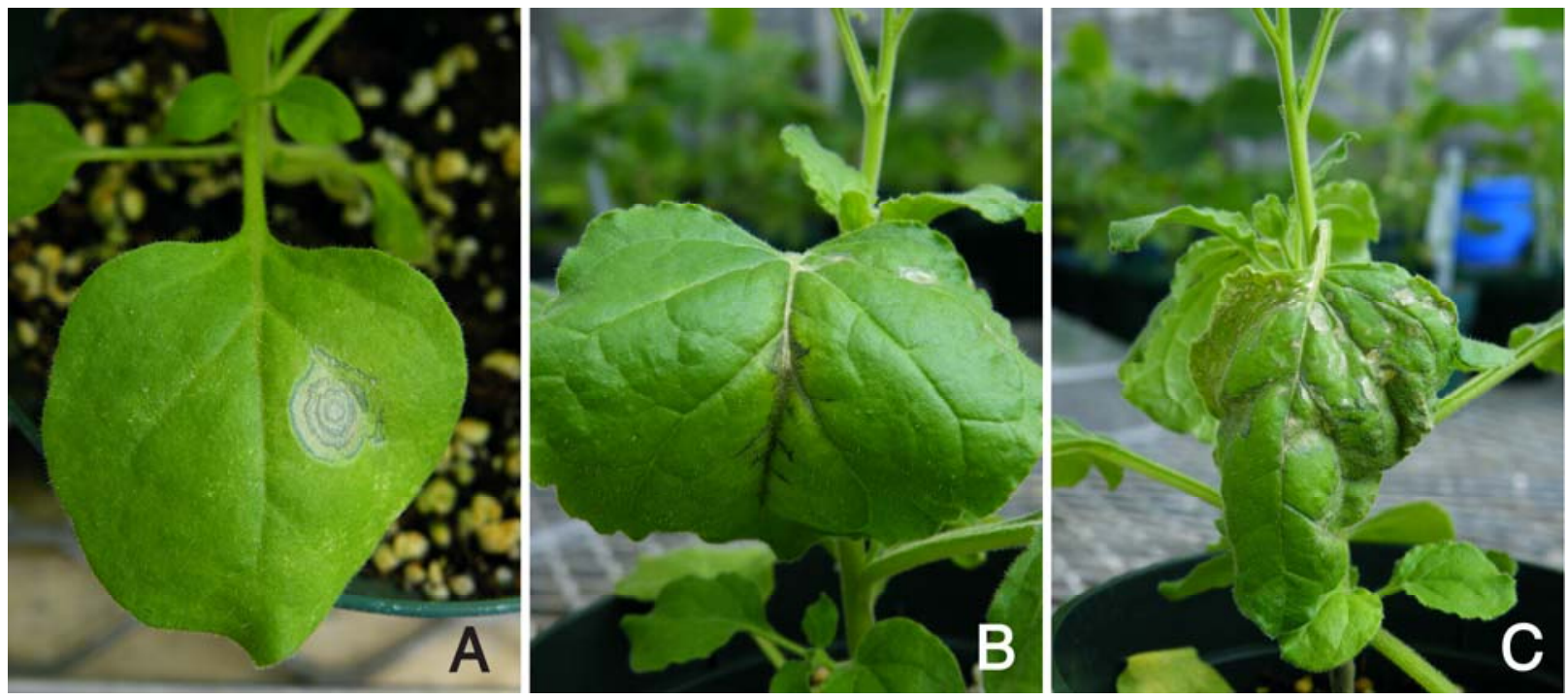

Fig. 3. Nicotiana benthamiana mechanically inoculated with Soybean vein necrosis-associated virus. A, Local lesion (1 week postinoculation); B, expanded lesion ( 2 weeks postinoculation); and $\mathbf{C}$, systemic infection (3 weeks postinoculation).
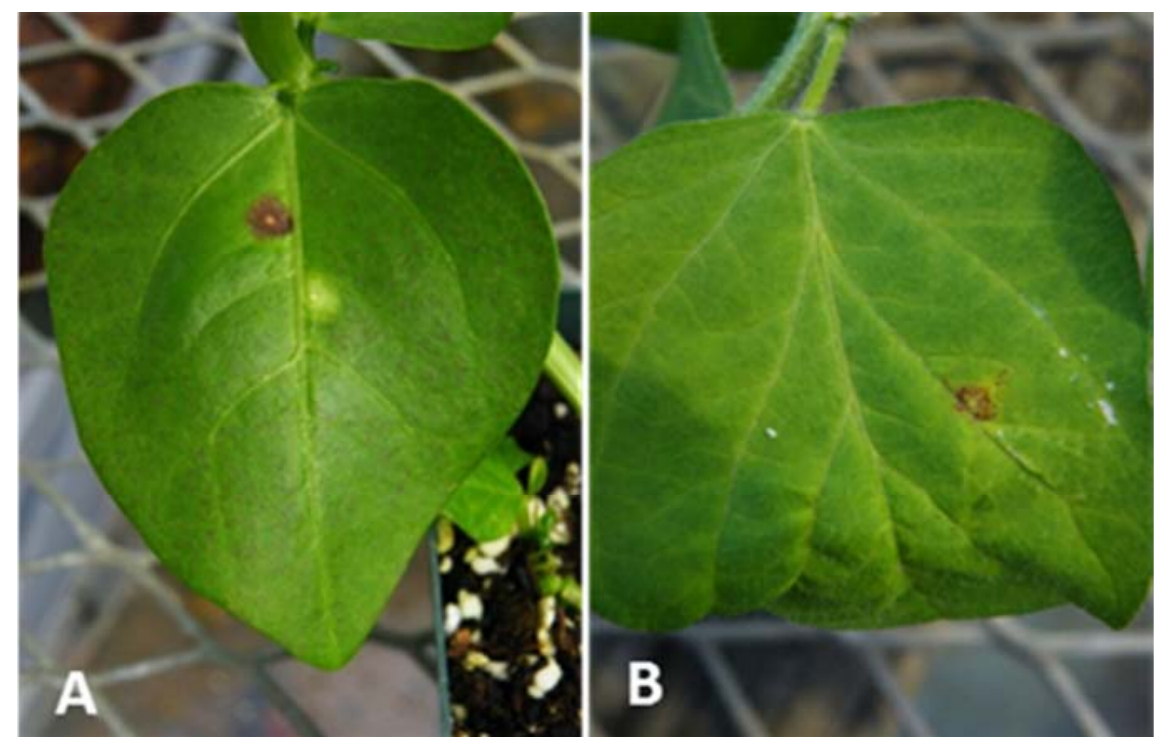

Fig. 4. Cowpea and soybean mechanically inoculated with Soybean vein necrosis-associated virus. A, Local lesion on cowpea (7 days postinoculation) and B, local lesion on soybean (9 days postinoculation). 
and Soybean mosaic virus, have been reported to cause damages in comparable geographic regions $(32,44)$ but none was found to emerge in such a short time frame and infect such high number of samples.

Variation in disease severity has been observed under similar environmental conditions, a possible result of the interaction between distinct virus strains and soybean cultivars. Diversity analysis of isolates collected from nine states revealed a relatively homogeneous population structure. Similarly, virus isolates collected from plants showing severe symptoms were very similar or identical to those infecting plants with mild symptoms. These results suggest that the symptom intensity observed in the field may be due to host genotype variation rather than distinct virus isolates. Other than affecting disease symptomology, the population structure of a virus may play a role in host adaptability $(1,8)$. The population structure analysis of $\mathrm{SVNaV}$ revealed a low genetic variability which was confirmed by Tajima's D test and the $d_{N s} / d_{S}$. This could be an indication that SVNaV may have recently moved to soybean from another host and there has not been enough time to diversify in its new host.

The detection protocol developed in this study provides sensitivity and universality, and is an invaluable tool in the further exploration of the biology of this emerging virus disease in North America. The host range study revealed additional legume species as $\mathrm{SVNaV}$ hosts. The localized infection in legume species suggests that these species are probably not the original hosts of the virus, given that long-term virus-host interactions tend to cause systemic infections favoring virus survival (23). Still, additional accessions and cultivars need to be tested to better support this hypothesis. The incidence of SVNaV as studied in this article perfectly overlaps with the natural distribution of ivyleaf morning glory in North America (4) and the soybean thrips in the midsouth (35), suggesting that this common weed may play a critical role in virus and disease epidemiology.

Soybean thrips are common pests in agriculture, infesting cotton, soybean, and other legume species $(21,29)$. Typical damage caused by this species includes leaf distortion, curling, or yellowing but has little economic impact (2). Our transmission assays fulfilled Koch's postulates for the virus, now renamed to Soybean vein necrosis virus (SVNV), and provided, for the first time, experimental evidence that soybean thrips are capable of transmitting a virus. The low virus infection rate obtained in mechanical transmissions compared with the high transmission efficiency of soybean thrips signifies the critical role of the vector in disease epidemics. With the data collected to date, it appears that control of the soybean thrips is the only approach available to reduce SVND incidence.

Out of the more than 5,000 thrips species, only 14 can transmit tospoviruses and, interestingly enough, all belong to the subfamily Thripinae (30). This article presents evidence that species in the subfamily Sericothripinae can also function as an efficient virus vector and transmit members of the Tospovirus genus, a property that may have significant impact on both ecological and evolutionary aspects of tospoviruses.

Sequence diversity, host range, and vector specificity are important properties in tospovirus classification $(7,17,19,26)$. Molecular characterization and phylogenetic analysis revealed SVNV as a distinct member of the genus Tospovirus, sharing minimal similarity with other members (46) other than Bean necrotic mosaic virus (6). Only Nicotiana spp. can sustain virus replication among the commonly used indicator species and soybean thrips transmission proved vector specificity, making SVNV a unique member of the group.

\section{ACKNOWLEDGMENTS}

This study was supported by grants from the Arkansas Soybean Promotion Board, the United Soybean Board and the National Science Foundation-Arkansas ASSET Initiatives II (EPS-1003970). We thank S. Kantartzi, S. Sabanadzovic, T. Allen, A. Collins, R. Mulrooney, E. Bush,

TABLE 2. Assay of transmission efficiency of Soybean vein necrosisassociated virus ( $\mathrm{SVNaV}$ ) by soybean thrips

\begin{tabular}{lcc}
\hline Cultivar name & $\begin{array}{c}\text { Number of } \\
\text { plants tested }\end{array}$ & $\begin{array}{c}\text { SVNaV-positive plants } \\
\text { (infection rate) }\end{array}$ \\
\hline Hutcheson & 7 & $7(100 \%)$ \\
Hutcheson & 8 & $8(100 \%)$ \\
Hutcheson & 9 & $9(100 \%)$ \\
Lee 68 & 9 & $6(66.7 \%)$ \\
\hline
\end{tabular}
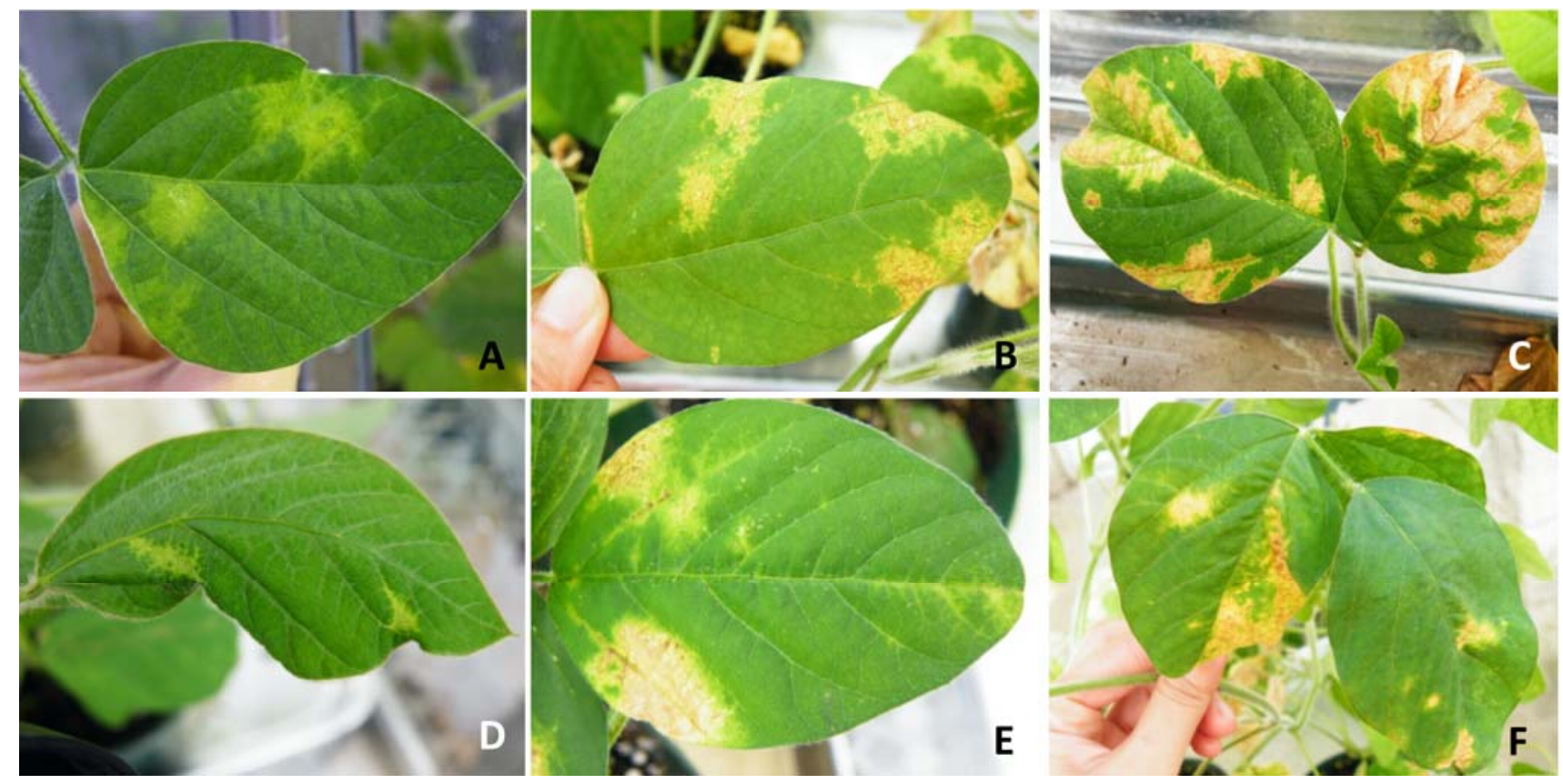

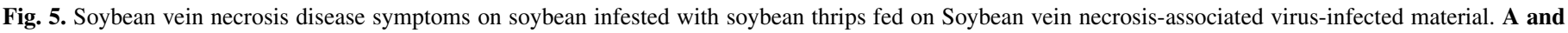

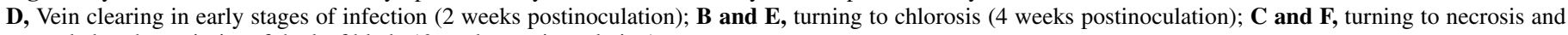
expanded to the majority of the leaf blade ( 6 weeks postinoculation). 
G. Bergstrom, and D. Johnson for their assistance obtaining virus isolates for the population study; and P. Chen, A. Whitfield, and N. Rayapati for intriguing discussions and inputs to the project.

\section{LITERATURE CITED}

1. Acosta-Leal, R., Duffy, S., Xiong, Z., Hammond, R. W., and Elena, S. F. 2011. Advances in plant virus evolution: Translating evolutionary insights into better disease management. Phytopathology 101:1136-1148.

2. Anonymous 2009. Soybean thrips: Sericothrips variablilis Beach. http:// extension.entm.purdue.edu/fieldcropsipm/insects/soybean-thrips.php

3. Anonymous. 2012. NCERA 200 Iowa Report. 2012 NCERA 200 Conference, Ames, IA.

4. Anonymous 2012. Plant profile-Ipomoea hederacea Jacq. ivyleaf morning-glory. http://plants.usda.gov/java/profile?symbol=iphe

5. Cho, J. J., Mau, R. F. L., Mitchell, W. C., Gonsalves, D., and Yudin, L. S. 1987. Host list of plant susceptible to tomato spotted wilt virus (TSWV). Res. Ext. Ser. Hawaii 10.

6. de Oliveira, A. S., Melo, F. L., Inoue-Nagata, A. K., Nagata, T., Kitajima, E. W., and Resende, R. O. 2012. Characterization of Bean necrotic mosaic virus: A member of a novel evolutionary lineage within the genus Tospovirus. PLoS One. 7:1-9.

7. Dewey, R., Semorille, L., Crisci, J., and Grau, O. 1996. Clustering of Argentinean tospoviruses with existing species in the genus by sequence analysis of a 450-nucleotide RNA region of the $\mathrm{N}$ gene. Virus Genes 13:255-262.

8. Elena, S. F., Carrasco, P., Daròs, J., and Sanjuán, R. 2006. Mechanisms of genetic robustness in RNA viruses. EMBO Rep.7:168-173.

9. Gee, A. 2012. New soybean virus found, confirmed in Indiana. http://www.purdue.edu/newsroom/releases/2012/Q3/new-soybean-virusfound,-confirmed-in-indiana.html

10. Gent, D. H., Lindsey, J. du T., Fichtner, S. F., Mohan, S. K., Pappu, H. R., and Schwartz., H. F. 2006. Iris yellow spot virus: An emerging threat to onion bulb and seed production. Plant Dis. 90:1468-1480.

11. Golnaraghi, A. R., Pourrahim, R., Farzadfar, S. Ohshima, K., Shahraeen, N., and Ahoonmanesh, A. 2007. Incidence and distribution of Tomato yellow fruit virus on soybean in Iran. Plant Pathol. J. 6:14-21.

12. Golnaraghi, A. R., Shahraeen, N., Pourrahim, R., Ghorbani, S., and Farzadfar, S. 2001. First report of Tomato spotted wilt virus on soybean in Iran. Plant Dis. 85:1290.

13. Han, J., Domier, L. L., Dorrance, A. E., and Qu, F. 2013. First report of Soybean vein necrosis-associated virus in Ohio soybean fields. Plant Dis. 97:693.

14. Huang, X., and Madan, A. 1999. CAP3: A DNA sequence assembly program. Genome Res. 9:868-877.

15. Inoue, T., Murai, T., and Natsuaki, T. 2010. An effective system for detecting Iris yellow spot virus transmission by Thrips tabaci. Plant Pathol. 59:422-428.

16. Jacobs, J. L., and Chilvers, M. I. 2013. First report of Soybean vein necrosis virus on soybeans in Michigan. Plant Dis. http://dx.doi.org/ 10.1094/PDIS-03-13-0242-PDN

17. Khatabi, B., Wen, R.-H., Hershman, D. E., Kennedy, B. S., Newman, M. A., and Hajimorad, M. R. 2012. Generation of polyclonal antibodies and serological analyses of nucleocapsid protein of Soybean vein necrosis associated virus: A distinct soybean infecting tospovirus serotype. Eur. J. Plant Pathol. 133:783-790.

18. Korber, B. 2000. HIV signature and sequence variation analysis. Pages 55-72 in: Computational Analysis of HIV Molecular Sequences. G. Allen, G. Rodrigo, and H. Learn, eds. Kluwer Academic Publishers, Dordrecht, The Netherlands.

19. Kunkalikar, S. R., Poojari, S., Arun, B. M., Rajagopalan, P. A., Chen, T. C., Yeh, S. D., Naidu, R. A., Zehr, U. B., and Ravi, K. S. 2011. Importance and genetic diversity of vegetable-infecting tospoviruses in India. Phytopathology 101:367-376.

20. Larkin, M. A., Blackshields, G., Brown, N. P., Chenna, R., McGettigan, P. A., McWilliam, H., Valentin, F., Wallace, I. M., Wilm, A., Lopez, R., Thompson, J. D., Gibson, T. J., and Higgins, D. G. 2007. ClustalW and ClustalX version 2. Bioinformatics 23:2947-2948.

21. McLeod, P. 2008. Identification, biology and management of insects attacking commercially produced vegetables in Arkansas. http:// comp.uark.edu/ pjmcleod/arkveginsects/legumes.html

22. Mian, R. A., and Qu, F. 2012. NCERA 200 Ohio Report. 2012 NCERA 200 Conference, Ames, IA.
23. Min, B.-E., Feldman, T. S., Ali, A., Wiley, G., Muthukumar, V., Roe, B. A., Roossinck, M., Melcher, U., Palmer, M. W., and Nelson, R. S. 2012 Molecular characterization, ecology, and epidemiology of a novel Tymovirus in Asclepias viridis from Oklahoma. Phytopathology 102:166-176.

24. Mohamed, N. A., Randles, J. W., and Franchi, R. I. B. 1973. Protein composition of Tomato spotted wilt virus. Virology 56:12-21.

25. Moritz, G., Kumm, S., and Mound, L. 2004. Tospovirus transmission depends on thrips ontogeny. Virus Res. 100:143-149.

26. Pappu, H. R., du Toit, L. J., Schwartz, H. F., and Mohan, S. K. 2006. Sequence diversity of the nucleoprotein gene of iris yellow spot virus (genus Tospovirus, family Bunyaviridae) isolates from the western region of the United States. Arch. Virol. 151:1015-1023.

27. Pappu, H. R., Jones, R. A. C., and Jain, R. K. 2009. Global status of tospovirus epidemics in diverse cropping system: Successes achieved and challenges ahead. Virus Res. 141:219-236.

28. Pietersen, G., and Morris, J. 2002. Natural occurrence of Groundnut ringspot virus on soybean in South Africa. Plant Dis. 86:1271.

29. Reed, J., Burris, E., Allen, C., Bagwell, R., Cook, D., Freeman, B., Herzog, G., Lentz, G., and Leonard R. 2001. Thrips (Thysanoptera: Thripidae) A multi-state survey: Summary of observations for Arkansas, Alabama, Georgia, Louisiana, Mississippi, and Tennessee. Miss. Agric. For. Exp. Stn. Res. Rep. 15.

30. Riley, D. G., Joseph, S. V., Srinivasan, R., Stanley, D. 2011. Thrips vectors of tospoviruses. J. Integr. Pest Manage. 1:1-10.

31. Sakurai, T., Inoue, T., and Tsuda, S. 2004. Distinct efficiencies of Impatiens necrotic spot virus transmission by five thrips vector species (Thysanoptera: Thripidae) of tospoviruses in Japan. Appl. Entomol. Zool. 39:71-78.

32. Sinclair, J. B., and Hartman, G. L. 1999. Introduction. In: Compendium of Soybean Diseases, 4th ed. G. L. Hartman, J. B. Sinclair, and J. C. Rupe, eds. American Phytopathological Society, St. Paul, MN.

33. Smith, D. L., Fritz, C., Watson, Q., Willis, K. D., German, T. L., Phibbs, A., Mueller, D., Dittman J. D., Saalau, E., and Whitman S. A. 2013. First report of Soybean vein necrosis disease caused by Soybean vein necrosisassociated virus in Wisconsin and Iowa. Plant Dis. 97:693.

34. Stobbs, L. W., Broadbent, A. B., Allen, W. R., and Stirling, A. L. 1992. Transmission of Tomato spotted wilt virus by the western flower thrips to weeds and native plants found in southern Ontario. Plant Dis. 76:23-29.

35. Sweeden, M. B., and McLeod, P. J. 1993. Seasonal occurrence of thrips (Thysanoptera) on cowpeas in western Arkansas and northeast Oklahoma. J. Entomol. Sci. 28:427-432.

36. Tajima, F. 1989. Statistical methods to test for nucleotide mutation hypothesis by DNA polymorphism. Genetics 123:585-595.

37. Tamura, K., Peterson, D., Peterson, N., Stecher, G., Nei, M., and Kumar, S. 2011. MEGA5: Molecular evolutionary genetics analysis using maximum likelihood, evolutionary distance, and maximum parsimony methods. Mol. Biol. Evol. 28:2731-2739.

38. Tenuta, A. 2012. First confirmation of Soybean vein necrosis virus in Ontario. http://fieldcropnews.com/2012/09/first-confirmation-of-soybeanvein-necrosis-virus-in-ontario

39. Tzanetakis, I. E., Halgren, A., Mosier, N., and Martin, R. R. 2007. Identification and characterization of Raspberry mottle virus, a novel member of the Closteroviridae. Virus Res. 127:26-33.

40. Tzanetakis, I. E., Wen, R.-H., and Newman, M. 2009. Soybean vein necrosis virus: a new threat to soybean production in Southeastern United States? (Abstr.) Phytopathology 99:S131.

41. Ullman, D. E., Meideros, R., Campbell, L. R., Whitfield, A. E., Sherwood, J. L., and German, T. L. 2002. Thrips as vectors of tospovirus. Adv. Bot. Res. 36:113-140.

42. Van de Wetering, F., Goldbach, R., and Peters, D. 1996. Tomato spotted wilt tospovirus ingestion by first instar larvae of Frankliniella occidentalis is a prerequisite for transmission. Phytopathology 86:900-905.

43. Whitfield, A. E., Ullman, D. E., and German, T. L. 2005. Tospovirusthrips interactions. Annu. Rev. Phytopathol. 43:459-489.

44. Wrather, J. A., and Koenning, S. R. 2009. Effects of diseases on soybean yields in the United States 1996 to 2007. Online. Plant Health Progress. doi:10.1094/PHP-2009-0401-01-RS

45. Zhou, J. 2012. Characterization and epidemiology of Soybean vein necrosis associated virus. M.S. thesis, University of Arkansas, Fayetteville.

46. Zhou, J., Kantartzi, S. K., Wen, R.-H., Newman, M., Hajimorad, M. R., Rupe, J. C., and Tzanetakis, I. E. 2011. Molecular characterization of a new tospovirus infecting soybean. Virus Genes 43:289-295. 